\title{
Probable Trends in University
}

\section{Libraries}

\author{
Harold L. Leupp is librarian at the \\ University of California.
}

$\mathrm{E}$ XCEPT in those state colleges which in reality are universities in all but name, recent years have witnessed few changes of a fundamental nature in the organization and operation of American college libraries. Material strides have been made in the size and strength of many collections, the scope of many has broadened, a larger proportion of the personnel is professionally competent, and reader accommodations have been considerably improved, but the underlying character of the college library as an institution does not seem to change much from decade to decade. Nor does there seem to be any obvious reason why it should. The colleges are free from most of those problems which advances in scientific discovery and technical achievement, and rapidly changing conceptions of man's relationship to man, social, economic, and political, have imposed upon the universities. The astonishing growth of graduate schools, the pressure upon every university to offer graduate work in ever new fields, and the increasing emphasis upon independent investigation in undergraduate courses, are developments of recent years with which university libraries are vitally concerned. Probably it was natural for university librarians to try to meet these changing conditions by adapting old methods and old conceptions, as well as old buildings, to new necessities. At any rate, that is what most of us did. It has become unhappily evident that that is not good enough : the whole situation needs to be restudied. Fundamental changes are called for, embodying conceptions of library service for universities which differ radically from those formerly held. Such changes ought to be carefully planned. The following remarks are intended to set forth some of the considerations involved, as $I$ see them.

Most university libraries and all state university libraries are at present called upon to serve two masters. There is Biblical warrant for the belief that such an attempt is unlikely to succeed, and experience seems to bear out the assumption. To try to care for the differing and often conflicting needs of hordes of undergraduate students on the one hand, and of graduate students, faculty, and research men on the other, in the same building or buildings, with the same collection of books, and very largely with the same staff, is to attempt the impossible. The answer seems to be separate housing, separate book collections, and separate staffs. The needs of most undergraduate and of practically all lower division students are simple, and can be met rather easily and at no great cost. It will simplify matters to eliminate from the present discussion this large and important but not very complicated element, and to consider only the 
problems of service to the more advanced group.

In broad terms, the problem of the university library is to provide materials for advanced instruction and research for the use of faculty and graduate students, in all fields in which the institution offers, or is likely to offer, graduate work, with emphasis placed in accordance with the instructional program; and to make these materials as accessible as possible, and their use as simple as possible, to the various groups which have need of them. This is about as elementary a statement as the situation permits, yet its implications are many and call for expenditure on a scale which no university has yet attempted. It has become the task of university librarians to sell some such conception of the university library to the powers that be as a preliminary to concrete proposals. Those proposals will have to deal in the light of local conditions with the problems of (I) assembling the collections, (2) housing them, and (3) administering them. Solutions will differ in detail, as the problems do, in different institutions, but any successful solution must take into account certain fundamental considerations.

\section{Assembling the Collections}

A definite program of acquisition should be adopted by the individual or group responsible for library policy. In most cases this will be the library committee. The program of acquisition should conform to the teaching and research program of the institution, which in turn will depend to some extent upon conditions and requirements imposed by geographical location, and should take into account both the resources and the programs of neighboring institutions of comparable character, and the means of making accessible the contents of collections further removed. It should be conditioned upon, or at least supplemented by, a comprehensive working plan for inter-institutional cooperation. The cooperating libraries should agree upon spheres of special interest, and each should so plan its purchasing program as not to attempt competition with any of the others in their special fields, confining itself to the acquisition simply of good working collections in those fields. Such a plan would place at the service of the scholar in any of the cooperating universities, many more outstanding collections than his own institution could ever hope to acquire. The next step, logically, would be joint purchasing of private libraries or special collections. Cooperation of this nature not only would enable the libraries in the group to take advantage of opportunities not financially posisible to any one of them alone, but would go far to eliminate the specter of excessive duplication which so often blights with cold dead hand, promising projects for purchase en bloc.

If I may illustrate the foregoing statements from our own recent experience: In I93 I our Library Committee drew up and presented to the Academic Senate, which formally approved it, a Special Report... on the Aims of the University Library, Based upon the Survey of the Collections. The objectives in view were stated to be:

. . f first, to build up the collections of books and documents more systematically; second, to avoid duplication of special collections, and to reduce the price-raising competition among libraries west of the Rockies by an interlibrary agreement as to special aims; third, to offer Friends of the University Library a concrete program for their support.

. $\therefore$ the statement herewith made of 
specific aims assumes the continued routine accumulation ... of all fundamental and indispensable books and documents, for teaching and research, in those fields covered by departments of the University. The aims indicated as Special are merely extensions of the fundamental collections....

Following a statement of basic immediate needs in all fields, comes the "Special Aims of the University Library," subdivided into (A) fields in which the library should strive for national preeminence, and (B) fields in which the library should maintain, or strive to attain, preeminence on the Pacific coast. The final paragraph lists ten fields in which the survey showed the library to be definitely below par, the aim being the development of satisfactory working collections. The recommendations in this special report have given definite direction to our purchasing program, and have determined its emphasis.

Within the last eighteen months the libraries of the University of California in Berkeley and in Los Angeles, which are independently administered and have no organic connection with one another, have joined forces to purchase abroad two important private collections, and are now negotiating the purchase of a third. Neither library could have financed these purchases alone, and extensive duplication would have resulted if it had done so. The plan adopted for this cooperative purchasing gives to the library having the greater strength in any of the fields concerned, the choice of material falling within those fields, and the cost is divided approximately in the ratio of the material acquired by each. The two collections purchased have been checked in both Berkeley and Los Angeles, and the net duplication proves to be comparatively slight.

\section{Housing the Collections}

Immediately there arises that hardy perennial, the question of centralization versus decentralization. The problem is not simple, but one thing may be stated definitely: in no large or rapidly expanding institution will the answer be found either in a single building, or in a battalion of departmental libraries. For one reason, on a far-flung campus the university $\mathrm{Ma}$ homet simply will not come to the mountain if the mountain is at any considerable distance from the center of his activities; and if that center is formed by laboratories, drafting rooms or shops, he has good grounds for his refusal. On the other hand, the cost of providing a reasonably complete library for every department of instruction would give pause even to Congress. Compromise is called for ; and in formulating a compromise program, university administrators should accept and embalm in their thinking two principles: ( I) In determining upon a site for and in planning any new building on the campus, the requirements of library service for the departments which will occupy that building should be given careful study; and (2) related departments should be grouped together, so far as may be possible.

While it is by no means true that all knowledge falls naturally into self-sufficient groupings of related subjects, it is a fact that the literature of certain groups of subjects tends to flock by itself, so to speak, evidencing only slight relationship to that of other subjects. In general, the organization of a university by department of instruction displays much the same tendency. In particular, this is true of the laboratory sciences and technology, which seems to indicate the lines on which decentralization may be effected with the 
greatest satisfaction to the departments concerned, and avoidance of most of the bad features of decentralization by departments. The essential conditions are: a group of departments dependent upon a common body of literature for which there is no considerable demand from outside the group; convenient location of the group library with respect to the departments constituting the group; concentration in the group library of all literature in classifications corresponding to the departments in the group; and administration of the group library in accordance with the regulations of the main library of the university, particularly as regards days and hours of opening, withdrawal privileges, and similar matters of general concern. The engineering departments constitute one such homogeneous and self-sufficient group; the biological sciences form one. Probably the literature of the social sciences and of the languages and literatures should be concentrated in the main library, since interest in it is not confined to the departments immediately concerned. Reserve collections for undergraduate courses should not be included in group concentrations, since considerations of efficiency and economy necessitate administration of reserve collections as units, regardless of subject matter.

\section{Administration of Collections}

The importance of developing subject specialists in university libraries (or rather as Dr. Peyton Hurt puts it, specialists in the literature of subjects) is generally conceded; a practical difficulty in attaining this ideal is lack of differentiation in the background of professional librarians. Languages, literature, art, music, history, economics, philosophy, psychology-these are offered in abundance, but rarely engi- neering, medicine, or anything in any science beyond the elementary work commonly required of candidates for the Bachelor's degree. Consideration of ways to improve this condition, happily is outside the scope of this paper, but the librarians in charge of group libraries should have, or should acquire, sufficient familiarity with the literatures of the subjects in their groups to enable them to be of real assistance to the experts they must serve, and also to contribute largely to the development of their respective libraries. Subject specialization perhaps is less vital on the staff of the main library, but even there, training in library technique and proficiency in foreign languages no longer suffice. To an increasing extent, more than average knowledge of the literature of some subject will be required of the professional staffs of university libraries, and in making appointments and promotions, university librarians will have to give more and more attention to diversification of the fields in which their staffs are qualified to render expert assistance. Logically, this should induce university administrators to offer greater inducements to library staff members to pursue graduate studies, and also should lead to changes in staff organization designed to secure for the library service the maximum benefit from the resulting special knowledge in subject fields. Subject specialists in any department of the library should be given training and experience in public work, and should be called upon to assist in developing the collections in their fields.

It seems probable that significant changes impend in the public catalog, possibly on the lines laid down by the John Crerar Library. The Crerar Library has an author catalog, and a classed catalog with index. The index consists of guide 
cards bearing subject headings, and references to the classes in which material on the subjects will be found. This index has been developed into a selected catalog by filing behind each guide, cards for the latest and most authoritative books on the subject. The plan combines the best features of the classed catalog for the specialist and the subject-word catalog for the layman, with the important additional advantage that the layman receives expert guidance in his choice of books. Competent librarians should be constantly on duty at the catalog to assist the user, and to maintain the important but insufficiently emphasized liaison between the public catalog and the special bibliographies and other library tools which supplement it.

\section{Old Idea Must Be Abandoned}

In conclusion, it seems inevitable that the old idea of planning for fifty years ahead, definitely must be abandoned. Universities are growing so rapidly, and conditions within them are changing so frequently and so radically, that any long term program becomes merely an invitation to trouble. At no point are the expansion of knowledge and the development of ideas static, and progress does not necessarily follow straight lines. Fields of knowledge tend constantly to overlap and merge, or to form new relationships. The subject groupings of today may be wholly changed tomorrow. One can only plan for the conditions which exist today or which there is reason to believe will soon exist, avoiding so far as possible any mortgaging of the future. Monumental library buildings, and programs which cannot be rapidly and fundamentally adjusted to changing conditions, do mortgage the future. Library buildings, like business buildings, should be designed to last for, say, twenty or twenty-five years, making way at the end of that time for new buildings, adapted to the changed requirements of the new day. Such a plan inherently is not impossible; the cost of one monumental library building, capitalized, probably would finance it for a century. The inestimable advantage this plan offers is, that under it the library building would subserve the requirements of scholarship. Librarians require no reminder of the unfortunate results of many attempts to fit those requirements to the Procrustean bed of a rigid architectural program. I have never heard the idea advanced that Omar was a university librarian, but certainly he expressed the heartfelt yearnings of many such, struggling to render adequate service in unadaptable tombs of literature, when he warbled to the girl friend:

Ah Love! could thou and I with Fate conspire

To grasp this sorry Scheme of Things entire,

Would not we shatter it to bits, and then Re-mould it nearer to the Heart's Desire!

\section{Discussion}

Charles W. Smith, librarian, University of Washington, commented on $\mathrm{Mr}$. Leupp's paper:

Mr. LeUPP has presented a succinct ac- count of the problems of the university library. All university librarians will recognize the correctness of his diagnosis and will doubtless agree as to the designated lines along which recovery must proceed. 


\section{Assembling the Collections}

Comment may first be made upon methods of assembling the collections. Librarians are willing to concede the potency of that new specific, Cooperation. The evils of competition are everywhere recognized, but what practical methods have been developed to combat them? I think we must say that so far coordination is the best answer. Progressive libraries are making self surveys of their fields of subject interest. In this way definite programs of book collecting are emerging and ultimately a national pattern may be discerned. Neighboring libraries are becoming acquainted with the subject fields being cultivated by institutions within given regions. So far so good, but all we have thus secured is awareness and the benefit of good intentions. What of the institutions which are frankly self centered? Such interinstitutional programs as can now be cited are due solely to the grace of God and a few benevolent and farsighted individuals. What agencies, we must ask ourselves, are available for securing group action or enforcing commitments?

It would be instructive to have fuller details in regard to the University of California survey of its library collections. Reference was made by Mr. Leupp to "an interlibrary agreement as to special aims." Was this agreement reached by a common conference at which the various institutions were represented and with what results? Will the California agreements be made known outside of the state? I am sure that each university library on the coast would profit by a knowledge of the California fields of specialization, even though they relate solely to its chief institution. Pacific coast universities are dependent to an unusual degree upon the holdings of this institution for interlibrary courtesies.

In the Pacific northwest we have found it a most difficult problem to reach interinstitutional agreements involving sacrifice or surrender of sovereignty. We have printed a preliminary list of special collections and certain libraries have been induced to assume special obligations. The Pacific Northwest Library Association, moreover, has proved a useful body for coordinating regional activity, but this body does not carry power to coerce administrative authorities or to prevent them from making unwise duplication of curriculums. In spite of considerable effort and undoubted progress, we still lack any competent central authority to secure and enforce educational cooperation. Our most successful work has been done in securing the adoption of regional responsibilities, especially in the collection of documents. Practically nothing has been accomplished by way of cooperative purchase.

California's experience in the joint purchase of special collections is most interesting and to an extent reassuring. One wonders, however, whether such agreements will not be much more difficult among wholly unrelated libraries. Obviously two institutions supported by a single state have a very close relationship.

\section{Housing}

The University of California is leading the way to a solution of the much mooted question of centralization versus decentralization of books. Branch libraries, grouped by large subjects, appear to be the only feasible solution for large institutions. With the growth of large collections and the large numbers served, some method of bringing books and users into 
close proximity is necessary. Where buildings permit, I think it ideal to have a number of these branches within the main library building. The branches, in any case, should be an integral part of the library system and under the full control of the librarian. Equal hours of opening and adequate reference service are indispensable factors. I agree that reserve collections for undergraduate courses should not as a rule be included in group concentrations. Particularly worth stressing is Mr. Leupp's observation that "in determining a site for and in planning any new building on the campus, the requirements of library service for the departments which will occupy the building must be given study."

Under the head of administration of the collections the importance of developing subject specialists is urged. This is essentially the ideal preached for many years by Mr. Henry at the University of Washington. Mr. Henry had very definitely in mind the idea of subject specialization when he insisted that a university library staff should be composed of a battery of trained reference librarians. Emphasis is now placed upon subject specialists, not alone in the reference division but in every department of the library, and for the main library is well as for the branches.

How to get them? Library schools give us some help, but much must be done to encourage on-the-job training. In our own staff we endeavor to get versatility when adding new members, but it is very necessary to stimulate continuous specialization. Those who register for university courses are, on approval of the divisional heads and the librarian, allowed three hours per week of library time for study. A university rule permits members of the library staff to audit courses without tuition fees when such courses are approved by the librarian. Normally a considerable number of the regular library staff are taking credit courses leading to advanced degrees. Advanced work is chosen with reference to increased usefulness to the library.

A few examples may be cited. A member of the Acquisitions Division in charge of Canadian documents is taking courses in English and Canadian history. The head of the science branch library has for some years carried work in the Russian language so as to be able to read and abstract Russian articles for the science men. Another staff member has for the past two years taken a daily course in the Chinese language in order to assist in the buying and cataloging of the Chinese collection augmented by a recent Rockefeller grant. Incidentally, apart from the subject knowledge gained, these librarian-teacher contacts have proved of great advantage. We have learned through these contacts how better to serve certain departments of instruction and we have been able to straighten out misunderstandings that have been discovered.

As an extra inducement toward staff specialization, one week of leave on pay in addition to the annual vacation is now permitted to staff members in consideration of professional projects undertaken during the year.

I heartily agree with Mr. Leupp that diversity of subject background is necessary. It is increasingly evident, however, that diversity can be secured by in-service training. Staff teamwork, moreover, is vital and training on the job tends to insure a harmonious development of the whole staff. 